\title{
SNAPSHOT: EL ENSUEÑO DE LOS ÁRBOLES - A REFLECTION
}

Ana Luisa Solis

[El Ensueño de los árboles was created in an intensive artistic residency in the remote Panamanian jungle village of Armila in the indigenous comarca of Guna Yala in June 2017, and premiered in Chapultepec, Mexico City in July 2017. The production took the form of a guided contemplative forest experience, incorporating key sensitization tools of the Taller, a central ritual action and poetic text. DM]

Daybreak - it is 7 in the morning and in the humidity and mud left by the night rain, the light is coming, and El Ensueño de los árboles (The Dreaming of Trees) begins in the sacred forest of Chapultepec.

We are kindly and delicately summoned by a group of actors to a theatrical, ecological tour through the forest.

With the instruction to keep silent and to open our eyes to the green space, we begin to walk paths among roots and trees... silence in the heart and an extended gaze to the whole landscape... attentive, attentive, attentive...

Deeply breathing the green freshness of the early morning, my wild look goes from top to bottom... A wet silence is fertilized by our Intent, inviting us to walk through the soft mud, contacting the shape and the magical, misty atmosphere of the trunks, branches and leaves pierced by thresholds of light. Breathing becomes such that it allows us to be suspended... A cool drop of fresh dew falls on my eye; 'Wake up', it says. But I do not want to wake up; it's a little cold and the path invites me to keep floating in a slow walk.

Once a teacher from India named Babaji said 'We are beings of the Forest'. I remember this and, through that memory, I enter into the experience.

The forest sings and the trees look at us with eyes of water, of hearts, of snakes - with arms extended towards the Earth and Heaven - deep eyes through which I let myself go towards I know not where... Tree eyes... I sigh. 
I am attentive to the fresh moment that renews the gaze and the breath. That moment contains everything and there is no word or thought that collapses it.

The body and mind become a delicate antenna that connects the sky with the roots in the Land of Trees. The hands simulate branches and extensions of the landscape, dancing in gratitude.

Everything fits together as we look at the timeless forest; its green jade injecting and healing me - reminding me that we are One in stillness, in calm, freeing ourselves and integrated with everyone.

Embracing the tree, I listen to the shaman's song and the tree sings and sings my heart and we all sing... a litany of wholeness and forgiveness is sent to heaven... 'Find the face you had before the world was made ${ }^{58}$. Looking inside, eyes closed, I enter the joyful universe of geometry, colors, light and movement. Joy, pure joy, that is my face before I was born.

I listen to myself telling me 'there are more senses in your body and mind than you imagine'... I discover new senses.

I hover and become space, light, geometry, tree! In this dream we become a tribe, rediscovering the origin of something that perhaps is called Love.

I want to cry with the trees; a weeping offering or a song of forgiveness that helps them to endure and to continue sheltering us... A song cried with joy.

Our breath of grateful audience communing with them.

Someone brought baraca [blessing] from the Guna community; yes, they managed to receive and bring back that offering through this dream. They wove themselves in the loom of the same Intent, in the loom of the shaman's song, with the jungle and the forest who are always our brethren.

I celebrate the shared adventure and I thank this tribe of dreamers; thank you for opening your hearts to this dreamlike, ecological, sacred theatre and for sharing it from your own dream...

58 This line, quoted from the performance, is a reference to the W.B. Yeats poem, 'Before the World was Made' (in W.B. Yeats (1929) The Winding Stair. New York: Fountain Press). 